\title{
GOOD CORPORATE GOVERNANCE PADA LEMBAGA PENDIDIKAN PESANTREN: STUDI PADA PONDOK PESANTREN UNIVERSITAS ISLAM INDONESIA
}

\author{
A Khumaedi Ja'far \\ Universitas Islam Negeri Raden Intan Lampung
}

Jl. Letkol H. Endro Suratmin, Kota Bandar Lampung, Lampung 35131

E-mail:khumeidi.jafar@radenintan.ac.id

Munawir

Pengawas Pendidikan Kabupaten Lampung Timur

Jl. Buay Selagai, Sukadana, Kabupaten Lampung Timur, Lampung 34194

E-mail:munawir.maridi@yahoo.co.id

\begin{tabular}{c|c|c}
\hline Received: & Revised: & Approved: \\
28/05/2018 & $17 / 07 / 2018$ & $20 / 09 / 2018$ \\
\hline
\end{tabular}

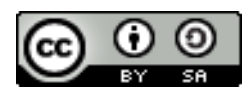

Good Corporate Governance Pada Lembaga Pendidikan Pesantren: Studi Pada Pondok Pesantren Universitas Islam Indonesia Licensed Under a Creative Commons Attribution-ShareAlike 4.0 International License

\begin{abstract}
Good Corporate Governance is a concept or guidance in managing a good organization or institution. Although, conceptually still leaves room for debate. However, most scholars agree on the concept. In the educational institutions context, especially pesantren institutions, the implementation of GCG is an important and interesting thing to study. This study is aimed in analyzing the implementation of GCG at the Islamic University of Indonesia Islamic Boarding School (PP UII). This research is a qualitative research with case study. In the process of data collection, researcher use observation, interview and documentation. The validation process uses the data and sources triangulation. In analysis, there are several stages, such as data reduction, data presentation, and conclusion drawing. The results of this
\end{abstract}


study, it can be seen that PP UII in principle has implemented the principles in GCG such as transparency, accountability, professionalism and responsibility. In the principle of transparency, PP UII reports every learning process and activities, also financial reports to the leaders of the university and the students can also find out the results of the learning evaluation. In the principle of professionalism, for example, it can be seen from the selection of scholarship awardee, the leadership process and the selection of lecturers in accordance with the competence. Also in the aspect of accountability and responsibility is implemented properly in PP UII.

Keywords: Good Corporate Governance, Education, and Boarding School.

\begin{abstract}
Abstrak
Good Corporate Governance merupakan konsep atau panduan dalam pengelolaan suatu lembaga atau organisasi yang baik. Meskipun secara konseptual masih menyisakan ruang perdebatan. Namun, sebagian besar pengkaji setuju terhadap konsep tersebut. Dalam konteks lembaga pendidikan, khususnya lembaga pesantren, pengimplementasian GCG merupakan suatu hal yang penting dan menarik untuk dikaji. Penelitian ini bertujuan untuk menganalisis implementasi GCG pada lembaga Pendidikan Pondok Pesantren Universitas Islam Indonesia. Penelitian ini adalah penelitian kualitatif dengan metode yang digunakan adalah studi kasus. Dalam proses pengambilan data, peneliti menggunakan teknik observasi, wawancara, dokumentasi. Proses validasi menggunakan proses triangulasi data dan sumber data. Adapun dalam analisisnya, terdapat beberapa tahapan yaitu reduksi data, penyajian data, dan penarikan kesimpulan. Berdasarkan hasil penelitian ini dapat diketahui bahwa PP UII secara prinsip telah mengimplementasikan prinsip-prinsip dalam GCG seperti transparansi, akuntabilitas, profesionalitas dan bertanggungjawab. Dalam aspek transparansi, PP UII melaporkan setiap proses pembelajaran dan kegiatan serta laporan keuangan kepada pihak pimpinan universitas dan para santri pula dapat mengetahui hasil evaluasi pembelajaran. Dalam aspek profesionalitas, misalnya dapat dilihat dari seleksi penerima beasiswa PP UII, proses kepemimpinan dan pemilihan dosen sesuai dengan bidang keilmuan dan kompetensi. Begitu juga dalam aspek akuntabilitas dan tanggungjawab diimplementasikan secara baik di PP UII.
\end{abstract}

Kata Kunci: Good Corporate Governance, Pendidikan, dan Pesantren. 


\section{A. Pendahuluan}

Pondok Pesantren merupakan lembaga pendidikan Islam tertua di Indonesia. Bahkan, Martin menyebut bahwa tradisi pengajaran agama Islam di Pesantren adalah salah satu tradisi agung (great traditon) di Indonesia. Mengapa demikian, karena hadirnya pesantren dimaksudkan untuk mentransmisikan Islam bercorak tradisional sebagaimana termuat dalam kitab kuning ke dalam wadah institusi pendidikan. ${ }^{1}$ Dalam proses transmisinya, semua komponen baik Kiai (pemimpin), santri atau murid maupun kurikulum harus terlibat secara sinergis. Semua komponen tersebut harus berjalan secara beriringan dalam mewujudkan tujuan suatu lembaga.

Dilihat dari sisi fungsinya, pesantren paling tidak memiliki tiga fungsi utama yang tidak dapat dipisahkan yaitu pertama, sebagai institusi keilmuan. Jika melihat klasifikasi keilmuan yang disebutkan Imam al-Ghazali, ilmu pengetahuan terbagi menjadi dua yaitu ilmu syariah yang dihukumi fardhu 'ain dan ilmu ghoiru syariah yang dihukumi fardhu kifayah. Berdasarkan hal tersebut, Pesantren masuk dalam core ilmu syariah yang berhukum wajib untuk dipelajari. Meskipun demikian, Pesantren juga harus mengembangkan keilmuan fardhu kifayah. Kedua, fungsi sebagai institusi keagamaan. pesantren sebagaimana core keilmuannya, maka tentu juga menjadi lembaga keagamaan. Pesantren berfungsi tidak hanya sebagai lembaga yang melakukan tugas pendidikan, pengajaran, pengembangan kajian keagamaan tetapi juga hadir dalam upaya perubahan sosial ke arah yang lebih baik. Ketiga, sebagai institusi sosial kemasyarakatan. Hal ini merupakan suatu yang wajar karena pesantren hadir di tengah masyarakat maka tidak dapat lepas dari masyarakat itu sendiri. Dalam proses transmisi fungsi sosial ini, pesantren melakukannya dengan kegiatan dakwah. ${ }^{2}$

Kehadiran pesantren di tengah masyarakat jelas membawa pengaruh yang luar biasa bagi pembinaan moral dan pengembangan pendidikan. Pesantren mempunyai fungsi ganda yaitu selain membina moral akhlak para santri juga turut serta dalam

${ }^{1}$ Martin Van Bruinessen, Kitab Kuning, Pesantren dan Tarekat (Yogyakarta: Gading Publishing, 2015), 85.

2 Atho' Lukman Hakim, "Pesantren dan Perubahan SosiaL" Vol. 1, No. 1 (Desember 2013): 23. 
mencerdaskan melalui pendidikan-pendidikan yang integralistik. Fungsi inilah yang kemudian juga direspon oleh Universitas Islam Indonesia. UII berbeda dengan Universitas lainnya dengan catur dharma yang menambahkan dakwah Islamiyyah (selain bidang pendidikan, penelitian dan pengabdian masyarakat) sebagai bagian integral dari dharma universitasnya. ${ }^{3}$ UII turut ambil bagian dalam proses pembinaan moral dan pengembangan pendidikan sekaligus melalui Pondok Pesantren Universitas Islam Indonesia. Inilah yang membedakan UII dengan perguruan tinggi lainnya.

Hal tersebut diperkuat dengan statuta dasar penyelenggaraan UII. Setidaknya, terdapat dua hal terkait hal tersebut pertama, Basic Philosophy, maksudnya dalam pengemangan keilmuan, UII tidak membedakan atau mendikotomi keilmuan agama dan non-agama. Kedua, dalam aspek aktivitas dan prilaku civitas akademika. Islam harus menjadi tata nilai yang dipraktikkan setiap civitas akademik, dengan istilah lain ruhul Islam menjadi pedoman dalam melakukan aktivitas, baik dalam kegiatan belajar maupun hubungan kepada sesama civitas akademika. ${ }^{4}$

Sebagai bagian dari implementasi statuta tersebut, khususnya dalam dharma dakwah Islamiyyah, UII berkomitmen mendirikan Pondok Pesantren Universitas Islam Indonesia (PP UII). PP UII merupakan program beasiswa unggulan yang ditujukan untuk menjaring bibit unggul yang tidak hanya menguasai bidang-bidang keilmuan agama saja, tetapi juga terintegrasi dengan keilmuan lainnya. PP UII berbeda dengan pondok pesantren pada umumnya. PP UII sebagai sebuah pesantren di bawah naungan yayasan memiliki peraturan atau regulasi yang disesuaikan dengan peraturan universitas. PP UII didesain sebagai wadah bagi para mahasiswa unggul yang mendapat beasiswa melalui proses seleksi yang ketat.

Dari sisi tujuan, PP UII berkomitmen untuk melahirkan intelektual muslim yang bertakwa, memiliki keunggulan di bidang pemikiran keagamaan, keilmuan dan ketrampilan, pengembangan riset dan akhlakul karimah serta melahirkan intelektual Muslim

3 "Statuta Universitas Islam Indonesia," t.t., Yogyakarta, Pasal 7, ayat 1. Juga, Pasal 12 ayat 1 .

${ }^{4}$ Ahmad Darmaji, dkk, "Reaktualisasi Dharma Dakwah Islamiyah Kampus UII Demangan" Vol. 10, No. 1 (Juni 2014): 37. 
yang berakhlak terpuji. ${ }^{5}$ Maka, dalam mewujudkan tujuan tersebut diperlukan pengelolaan dan tata kelola yang baik. Tidak hanya dari unsur pimpinan saja, tetapi juga diperlukan kerjasama sinergis antara pimpinan, pengasuh, pengelola dan santri.

Suatu lembaga sudah seharusnya melakukan pengelolaan yang baik untuk mewujudkan suatu lembaga yang telah direncanakan. Pengelolaan yang baik pada suatu lembaga pada perkembangannya dikenal dengan istilah Good Corporate Governance (GCG). GCG merupakan sistem pengelolaan lembaga secara baik dengan berbagai prinsip-prinsip dasar seperti transparansi, akuntabilitas, profesional dan bertanggung jawab. ${ }^{6}$ Maka, suatu lembaga dapat dikatakan baik jika dapat sesuai dengan prinsip-prinisp dalam GCG, termasuk dalam hal ini adalah PP UII. Lalu, Ayang menjadi pertanyaan kemudian ialah bagaimana implementasi GCG dalam konteks PP UII, apakah prinisp-prinisp GCG telah diimplementasikan pada PP UII?

Penelitian ini adalah penelitian kualitatif dengan metode studi kasus. ${ }^{7}$ Dengan metode ini, penulis dapat mengungkap dan mengelaborasi secara lebih komprehensif dan kemudian melakukan analisis secara mendalam. Dalam proses pengambilan data, peneliti sebagai instrumen inti, terjun langsung ke lapangan dengan menggunakan teknik observasi, wawancara, dokumentasi. Peneliti secara langsung mengobservasi Pondok Pesantren Universitas Islam Indonesia yang terletak di Jalan Selokan Mataram, Dabag, Desa Condong Catur, Kabupaten Sleman, Daerah Istimewa Yogyakarta. Dalam wawancaranya, peneliti mewancarai pengelola Pesantren, Dosen, tenaga pengabdian dan santri. Peneliti juga melakukan dokumentasi dari Peraturan Universitas Nomor 17/PU/Rek/ VIII/2011 tentang Pondok Pesantren Universitas Islam Indonesia dan juga jurnal-jurnal terkait dengan tema tulisan ini yaitu tentang pesantren dan good corporate governance.

5 "Peraturan Universitas Nomor 17/PU/Rek/VIII/2011 tentang Pondok Pesantren Universitas Islam Indonesia," t.t.

${ }^{6}$ Adebayo, Mudashiru., Ibrahim, A.O. Bakare., Yusuf, Babatunde., \& Omah, Ishmael, "Good Corporate Governance and Organisational Performance: An Empirical Analysis" Vol. 4, No. 7(1) (2014): 172.

${ }^{7}$ Agus Salim, Teori dan Paradigma Peenelitian Sosial (Yogyakarta: Tiara Wacana, 2001), 151. 
Untuk menguji keabsahan data guna menegaskan bahwa data-data yang didapat dari lapangan adalah valid, maka peneliti menggunakan proses triangulasi. Triangulasi adalah proses validasi yang dilakukan dalam penelitian untuk menguji kesahihan antara sumber data dengan sumber data lain, antara suatu metode dengan metode lainnya. ${ }^{8}$ Ada beberapa jenis triangulasi, ${ }^{9}$ namun dalam penelitian ini, peneliti menggunakan jenis triangulasi data dan sumber data. Peneliti membandingkan data dalam realitas dengan peraturan dan hasil wawancara dengan pengelola, dosen, tenaga pengabdian dan juga santri. Adapun dalam analisis, peneliti menggunakan tahapan yaitu reduksi data, penyajian data, dan penarikan kesimpulan. Semua komponen tersebut saling berkaitan dan bersangkutan pada saat sebelum, proses penelitian dan juga pasca pengambilan data.

\section{B. Good Corporate Governance}

Menurut Badan Pengawas Keuangan dan Pembangunan, ${ }^{10}$ Good Corporate Governance yang selanjutnya penulis singkat dengan GCG didefinisikan sebagai komitmen, aturan, serta praktik penyelenggaraan usaha secara beretika. Suatu perusahaan atau lembaga yang berbadan hukum diharapkan memiliki GCG yang bertujuan untuk menjaga keuangan atau sistem perekonomian. Definisi corporate governance juga dirumuskan oleh Jill, dkk, yang dikutip oleh Adebayo, $\mathrm{dkk}^{11}$ yaitu sistem pengawasan baik internal maupun eksternal perusahaan, yang menjamin bahwa perusahaan akan melaksanakan kewajibannya kepada pihak-pihak yang berkepentingan dengan perusahaan (stakeholders) dan bertindak dengan tanggung jawab sosial dalam segala bidang dari bisnis perusahaan yang bersangkutan.

${ }^{8}$ Mohammad Ali, Memahami Riset Perilaku dan Sosial (Bandung: Pustaka Cendikia Utama, 2011), 257; Lihat pula dalam karya yang lain Mohammad Ali, Metodologi dan Aplikasi Riset Pendidikan (Bandung: Penerbit Pustaka Cendikia, n.d.).

9 Britha Mikkelsen, Metode Penelitian Partisipatoris dan Upaya-upaya Pemberdayaan; Sebuah Buku Pegangan bagi Para Praktisi Lapangan (Jakarta: Yayasan Obor Indonesia, 2003), 96.

10 “BPKP RI," diakses 20 Agustus 2018, http:/ / bpkp.go.id/dan/konten/299/ Good-Corporate.bpkp.

11 Adebayo, Mudashiru., Ibrahim, A.O. Bakare., Yusuf, Babatunde., \& Omah, Ishmael, "Good Corporate Governance and Organisational Performance: An Empirical Analysis," 172. 
Corporate governance adalah sebuah istilah yang luas yang menjelaskan mengenai proses, kebiasaan, kebijakan, hukum dan institusi yang mengarahkan pengelolaan organisasi, lembaga, ataupun perusahaan. Adanya corporate governance adalah upaya lembaga, organisasi atau perusahaan untuk mencapai tujuannya serta mengelola hubungan antara stakeholder dan pemegang saham. selain itu, adanya corporate governance yang baik juga menjadi standar penting untuk membangun lingkungan kompetitif yang kuat untuk memfasilitasi keberhasilan untuk lembaga, organisasi, maupun perusahaan. ${ }^{12}$

Definisi mengenai good corporate governance lainnya dikemukakan oleh Monks dan Minow ${ }^{13}$ bahwa GCG merupakan suatu sistem yang berfungsi mengatur dan memberikan kendali pada perusahaan dalam kaitannya dengan penciptaan citra baik atau nilai tambah bagi perusahaan. Adapun pada tahun berikutnya Monks dan Minow pada buku yang berbeda mendefinisikan GCG sebagai tata kelola perusahaan yaitu sebagai hubungan antara berbagai komponen dalam sebuah perusahaan dalam menentukan arah dan kinerja perusahaan, lembaga, ataupun organisasi. ${ }^{14}$

Definisi lainnya diutarakan oleh Sidharta dan Cynthia ${ }^{15}$ bahwa good corporate governance merupakan sistem atau aturan yang baik dalam pengelolaan perusahaan dengan tujuan untuk meningkatkan nilai pemegang saham serta mengakomodasikan ke berbagai pihak yang berkepentingan dengan perusahaan (stakeholder), seperti kreditur, pemasok, asosiasi bisnis, konsumen, pekerja, pemerintah dan masyarakat luas. Sehingga terwujudlah kinerja perusahaan yang sehat.

Berdasarkan beberapa definisi maka dapat disimpulkan bahwa GCG merupakan suatu aturan yang digunakan untuk mengelola (2011): 2.

${ }^{12}$ Humera Khan, "A Literature Review of Corporate Governance" Vol.25

${ }^{13}$ Monks, R. A. G., \& Minow, N, Corporate Governance. New Jersey: Blackwell. Dikutip oleh Prabaningrat dan Widanaputra, "Pengaruh Good Corporate Governance dan Konservatisme Akuntansi pada Manajemen Laba" 10 (3), (2015): 666.

${ }_{14}$ Wajdi Ben Rejeb dan Mohamed Frioui, "The Impact of Good Corporate Governance Practices on Stakeholders Satisfaction in Tunisian Listed Companies" 4 (2) (2012): 189.

${ }_{15}$ Dwi Astika Sari, "Pengaruh good corporate governance terhadap manajemen laba," t.t., 3 . 
perusahaan agar pencapai tujuan perusahan sehingga meningkatkan nilai baik perusahaan di depan semua pihak yang berkepentingan.

\section{Prinsip-prinsip Good Corporate Governance}

Terdapat empat prinsip dari GCG yaitu tanggung jawab, akuntabilitas, keadilan dan transparansi. ${ }^{16}$ Adapun masing-masing prinsip GCG secara terperinci sebagai berikut:

1. Tanggung jawab dimaksudkan pada pengakuan atas semua hak yang terlibat dalam suatu lemabaga tersebut. Tanggung jawab juga dapat dipraktekkan melalui partisipasi dan keterlibatan para pemangku kepentingan dalam pengambilan keputusan strategis.

2. Akuntabilitas yaitu kecenderungan organisasi, lembaga, atau perusahaan untuk memberikan penjelasan dan pembenaran kepada para pemangku kepentingan terkait kinerja. Selain itu, akuntabilitas menentukan sejauh mana pemangku kepentingan memiliki akses ke informasi yang memadai, akurat, mudah dipahami, terkini, yang menjadi landasan untuk pengambilan keputusan. Adanya operasionalisasi akuntabilitas memungkinkan lembaga untuk menerima evaluasi yang lebih baik dari luar.

3. Keadilan, prinsip keadilan memiliki dua perspektif yaitu melindungi semua kepentingan dan memastikan perlakuan yang adil dari para pemangku kepentingan. Sedangkan yang kedua adalah Mempraktekkan keadilan dalam pengambilan keputusan dan dalam berurusan dengan pemangku kepentingan.

4. Transparansi berarti bahwa lembagamengungkapkan sesuatuyang memadai dan informasi yang tepat waktu kepada para pemangku kepentingan mengenai atau pimpinan terkaitpelaksanaan kelembagaan. Informasi-informasi tersebut berkaitan dengan kinerja keuangan, tata kelola maupun program kegiatan.

${ }^{16}$ Wajdi Ben Rejeb dan Mohamed Frioui, "The Impact of Good Corporate Governance Practices on Stakeholders Satisfaction in Tunisian Listed Companies," 190. 
Sedangkan menurut Nalim ${ }^{17}$ pada umumnya prinsip GCG terdiri dari lima yaitu transparancy, accountability, responsibility, independency, dan fairness. Namun forum for corporate governance in Indonesia menyebutkan ada empat prinsip yaitu fairness, transparancy, accountability, dan responsibility seperti yang disebutkan di atas. Lain halnya dengan Syakhroza yang menambahkan elemen lainnya seperti 1) memusatkan perhatian kepada board, 2) peraturan dan hukum sebagai alat untuk mengarahkan dan mengendalikan, 3) pengelolaan sumber daya organisasi secara efektif, efisien, ekonomis, dan produktif, 4) tujuan organisasi, serta 5) strategic control.

\section{Profil dan Sistem Pendidikan Pondok Pesantren Universitas Islam Indonesia (PP UII)}

PP UII secara geografis terletak di Desa Nologaten Kecamatan Condong Catur Kabupaten Sleman, Provinsi Yogyakarta, tepatnya di Jalan Selokan Mataram, Dusun Dabag. Secara geografis, PP UII sangat strategis karena terletak di jantung Yogyakarta. Berbagai kampus terletak tidak jauh dari Pesantren. Paling tidak, terdapat beberapa kampus yang mengitari PP UII di antaranya UIN Sunan Kalijaga, Universitas Sanata Dharma, AMIKOM, YKPN, UPN, Universitas Atma Jaya, Universitas Negeri Yogyakarta, Universitas Gadjah Mada, Universitas Mercu Buana, Fakultas Ekonomi UII dan PPs FIAI UII. ${ }^{18}$

Hadirnya PP UII dilatarbelakangi oleh spirit dan semangat para founding fathers UII untuk mencetak generasi yang menjunjung tinggi nilai-nilai keindonesiaan dan keislaman. UII sebagai kampus Islam tertua di Indonesia yang berdiri bertepatan dengan 8 Juli 1945, memiliki tanggung jawab moral untuk mengiring kemerdekaan Indonesia dengan spirit yang bersumber dari nilai-nilai keislaman. Prinsip dasar yang dijunjung ialah bagaimana generasi yang lahir dari PP UII menerapkan prinsip "berilmu amaliah dan beramal ilmiah." Potensi dua hal tersebut yang selalu ditanamkan kepada para pelajar di UII. Selain hal penting tersebut, UII memiliki Catur Dharma sebagai asas dasar yang juga mengedepankan dakwah Islamiyah sebagai

17 Nalim, "Good Corporate Governance dalam Islam," diakses 21 Maret 2018,https://media.neliti.com/media/publications/37052-ID-good-corporategovernance-dalam-perspektif-islam.pdf.

${ }^{18}$ Hasil observasi pada tanggal 18 Agustus 2018. 
bagian tak terpisahkan dari statuta UII. Misi ini yang kemudian menghendaki agar UII melahirkan generasi yang memiliki integritas yang tinggi terhadap keilmuan sekaligus berkepribadian islami yang berakar pada tauhid. ${ }^{19}$

Tanggung moral untuk melahirkan generasi yang bermanfaat bagi masyarakat tercermin dalam visi dan misi dan tujuan PP UII. Visi PP UII adalah terwujudnya Pondok Pesantren Universitas Islam Indonesia yang rahmatan lil 'alamin, memiliki keunggulan dan kompetensi keilmuan, keislaman dan dakwah. Adapun misi Pondok Pesantren UII adalah mencetak kader-kader umat yang memiliki keunggulan dan kompetensi di bidang pemikiran keagamaan, keilmuan, keterampilan, pengembangan riset, dan akhlakul karimah. Sedangkan tujuan PP UII adalah melahirkan intelektual muslim yang bertakwa, memiliki keunggulan di bidang pemikiran keagamaan, keilmuan dan ketrampilan, pengembangan riset dan akhlakul karimah serta melahirkan intelektual Muslim yang berakhlak terpuji. ${ }^{20}$

Atas dasar itu, UII membuka program beasiswa Pondok Pesantren yang semuanya akan ditanggung dan dibiayai oleh UII. penjaringan mahasiswa dilakukan seleksi secara ketat dan dibina dalam sebuah wadah pesantren,yang dikombinasikan dengan pendidikan regular starta 1 di fakultas yang ada di UII sesuai dengan bidang keminatan, sehingga nantinya para lulusannya dapat sesuai dengan apa yang dicita-citakan oleh UII. ${ }^{21}$ Program ini awalnya (tahun 1996) hanya ditujukan bagi Fakultas Tarbiyah dan Fakultas Syariah (sekarang menjadi Fakultas Ilmu Agama Islam atau FIAI). Namun dalam perkembangannya, program beasiswa unggulan PP UII tidak hanya untuk kedua fakultas tersebut, tetapi dibuka untuk fakultas lainnya kecuali Fakultas Kedokteran. Semula, PP UII hanya diperuntukkan pula bagi putra, namun pada tahun 2011 PP UII membuka program ini bagi pelajar putri. ${ }^{22}$

19 Djauhari Muhsin, Sejarah dan Dinamika Universitas Islam Indonesia (Yogyakarta: Universitas Islam Indonesia, 2002), 232.

20 "Peraturan Universitas Nomor 17/PU/Rek/VIII/2011 tentang Pondok Pesantren Universitas Islam Indonesia."

${ }^{21}$ Djauhari Muhsin, Sejarah dan Dinamika Universitas Islam Indonesia, 232.

${ }^{22}$ Ustadz Iqbal Zen, M.H, wawancara, 15 Agustus 2018. 
Awalnya, lulusan PP UII diproyeksikan untuk kembali mengabdi ke daerah asal. Hal ini karena proses rekruitmen juga melalu rekomendasi dan pilihan daerah setempat. Tujuan ini dimaksudkan untuk menguatkan dan mengenalkan secara lebih luas kiprah UII di masyarakat. Ini merupakan program yang digagas oleh UII bahwa setelah purna studi, alumni PP UII diwajibkan untuk mengabdi sebagai proses penempaan dan "penghalalan" beasiswa yang telah didapatkan. Namun demikian, seiring berjalannya waktu, hal ini tidak dapat dilaksanakan dengan baik karena berbagai faktor. Salah satunya karena birokrasi yang cukup rumit, proses penempatan dan lain sebagainya. Berdasarkan problem ini, maka pihak UII mengambil kebijakan bahwa pengabdian para santri purna tugas adalah di UII sesuai dengan instruksi penempatan dari rektor. Adapun lama pengabdian ini adalah selama satu tahun. ${ }^{23}$

Secara formatur, PP UII mempunyai tiga komponen kepemimpinan yaitu Rektor, Dewan Tanfidziyah dan Kiai atau pengasuh. Unsur pertama yaitu rektor yaitu pimpinan tertinggi yang menjalankan tugas dan fungsi UII termasuk di bawahnya adalah PP UII. Karena itu, setiap keputusan penting harus mendapat persetujuan rektor. Unsur kedua adalah dewan tanfidziyah yang merupakan pejabat struktural di lingkungan UII, dalam hal ini adalah dekan di setiap fakultas dan wakil rektor III. Dewan tanfidziyah bertugas mengawal keberlangsungan sistem dan proses pembelajaran di PP UII. sedangkan unsur ketiga adalah pengasuh yang bertugas sebagai pengurus harian yang tinggal bersama para santri di lingkungan PP UII. ${ }^{24}$ selain ketiga unsur tersebut, PP UII juga merekrut tenaga administrasi dan pengelola yang secara langsung diamanahi melalui Surat Perintah Kerja (SPK) yang bertandatangan rektor. Selain itu, terdapat pula santri pengabdian yang juga turut membantu dalam pelaksanaan kegiatan di pesantren. ${ }^{25}$

Tanggung jawab kepemimpinan yang berat pada pemimpin harian, maka Kiai dibantu oleh beberapa pengurus dan tenaga harian, selain juga terdapat organisasi santri yang membantu dalam

${ }^{23}$ Ustadz Muhammad Anas, S.Pd.I, wawancara, Juli 2018.

24 "Surat Rektor tentang Pedoman Penyelenggaraan Pondok Pesantren UII tahun 2002.," t.t.

${ }^{25}$ M Ainun Najib (Tenaga Pengabdian, wawancara, 16 Maret 2018. 
menjalankan program harian. Sehingga model kepemimpinan yang diterapkan adalah kepemimpinan kolektif. Sistem kepemimpinan yang tidak menjadikan Kiai sebagai aktor sentral dalam menjalankan roda pembelajaran, tetapi kepemimpinan yang saling menguntungkan. ${ }^{26}$ Adapun dalam proses pembelajaran, Kiai tidak seorang tunggal dalam mengajar para santri. Proses pembelajaran yang dilakukan pada setiap habis maghrib dan Isya diampun oleh masing-masing dosen baik dari lingkungan UII maupun dari luar UII dengan kualifikasi tertentu seperti linieritas keilmuan dan berstrata master. ${ }^{27}$

Adapun Sistem pendidikan yang diterapkan pada pesantren pada umumnya. Jika pada lembaga pendidikan pesantren tradisional, proses pembelajaran lebih didominasi oleh sentralitas Kiai atau ustadz. Begitu juga pada sebagian pondok modern yang menerapkan model pembelajaran serupa. Hal berbeda dengan PP UII yang melaksanakan program pendidikannya dengan menggabungkan sistem pesantren tradisional dengan Perguruan Tinggi. Pengadopsian sistem Perguruan Tinggi dapat dilihat dari penggunana Satuan Kredit Semester (SKS). Adapun sistem pesantren tradisional yang dimaksud ialah tetapnya penggunaan kitab klasik maupun kontemporer dalam kajian-kajiannya. ${ }^{28}$

Pembelajaran yang dilaksanakan di PP UII tidak sekedar diampu begitu saja, tetapi terdapat standarisasi keilmuan atau kepakaran tertentu. Misalnya, tenaga pengajar dengan minimal strata 2 atau memiliki ketokohan dan kepakaran pada bidang tertentu. Tenaga pengajar tidak hanya berasal dari lingkungan UII saja, tetapi juga berasal dari lintas Universitas maupun Pondok Pesantren seperti Universitas Islam Negeri Sunan Kalijaga, Pondok Pesantren Krapyak maupun Pondok Pesantren Wahid Hasyim Yogyakarta. ${ }^{29}$

Secara akademik, seluruh santri memilik standarisasi minimal untuk tetap berstatus sebagai santri penerima beasiswa unggulan.

${ }^{26}$ Untuk lebih detail terkait tipe kepemimpinan tersebut dapat dibaca di Kasful Anwar US, "Kepemimpinan Kiai Pesantren: Studi terhadap Pondok Pesantren di Kota Jambi" Vol. 25, No. 2 (2010): 228-32.

${ }^{27}$ Noor Hamid dan Muhammad Iqbal Juliansyahzen, "Prophetic Leadership in Pesantren Education: Study at Pondok Pesantren Universitas Islam Indonesia" Vol. 6, No. 2 (t.t.): 364 .

${ }^{28}$ Hasil observasi dan Ustadz Iqbal Zen, M.H, wawancara.20 maret 2018 ${ }^{29}$ Ustadz Iqbal Zen, M.H. 
Standarisasi ini dapat dilihat dari pencapaian Indeks Prestasi (IP). Bagi santri yang mengambil jurusan atau fakultas non-exact, maka diwajibkan mencapai nilai IP Kampus minimal 3,25 dan IP Pesantren minimal 3,00. Sedangkan bagi santri yang berstatus sebagai mahasiswa fakultas exact maka harus mencapai batas minimal IP Kampus adalah 3,00 dan IP Pesantren adalah 3.00. jika santri tidak mencapai standar minimal tersebut, untuk kali pertama maka santri yang bersangkutan diberikan Surat Peringatan, namun jika terjadi untuk yang kedua kalinya maka santri tersebut akan diberhentikan sebagai penerima beasiswa unggulan PP UII. ${ }^{30}$

Dalam proses pembelajarannya, kurikulum yang diaplikasikan terbagi ke dalam beberapa kelompok bidang keilmuan seperti keahlian atau keterampilan akademik, keterampilan hidup dan keterampilan sosial. Ketiga kelompok tersebut tersebar ke dalam 20 mata kuliah yang terdiri dari 42 SKS yang ditempuh selama tujuh semester.

PP UII juga memberlakukan pembelajaran-pembelajaran kepada santri lainnya dengan berbagai kegiatan yang dalam ilmu pendidikan disebut hidden curriculum. Beberapa kegiatan tersebut di antaranya kegiatan rutin malam jumatan (sharing). Kegiatan tersebut merupakan forum berbagai gagasan, ide, masukan untuk pesantren bahkan kritik terhadap sistem maupun kepemimpinan pesantren. Kegiatan lainnya semisal pembinaan bakat santri melalui organisasi internal seperti latihan debat bahasa Arab maupun Inggris, maupun seni lainnya.

\section{E. Implementasi Good Corporate Governance Pada Pondok Pesantren UII}

Secara kelembagaan, Pondok Pesantren Universitas Islam Indonesia memiliki struktur yang jelas. Suatu lembaga yang baik harus memiliki struktur yang jelas dengan penjelasan fungsi dan tugasnya masing-masing. Ini juga bagian atau ikhtiar PP UII dalam mewujudkan prinsip pengelolaan yang baik (Good Corporate Governance). Pengelolaan yang baik diharapkan dapat menghasilkan lulusan yang juga baik. Secara organisatoris, bentuk maupun sifat

${ }^{30}$ Noor Hamid dan Muhammad Iqbal Juliansyahzen, "Prophetic Leadership in Pesantren Education: Study at Pondok Pesantren Universitas Islam Indonesia," 364. 
secara jelas telah diuraikan pada Peraturan Universitas Nomor. 17/ PU/Rek/VIII/2011.

Secara kelembagaan, sebagaimana disebutkan diatas dapat dijelaskan sebagai berikut:

1. PP UII berada di bawah koordinasi Direktorat Pendidikan dan Pengembangan Agama Islam (DPPAI) yang bentuk secara langsung oleh rektor.

2. Dalam rangka pengelolaanya kemudian dibentuk Dewan Taujih, Dewan Tanfidz dan Wakil dewan dosen.

3. Dewan taujih dipimpin oleh Wakil Rektor III yang terdiri dari Direktur DPPAI, Pengasuh atau Kiai, dan Dekan di lingkungan UII. Dewan Taujih bertugas memberikan pertimbangan, saran atau masukan terhadap kemajuan Pesantren.

4. Dewan Tanfidz dipimpin oleh Pengasuh yang terdiri dari wakil pengasuh dan wakil dewan dosen yang bertugas merencanakan dan melaksanakan program kerja Pondok Pesantren.

5. Wakil dewan dosen terdiri dari beberapa dosen pondok pesntren (sekurang-kurangnya 2 dosen) yang dipilih oleh forum rapat dewan dosen untuk mewakili dosen-dosen dalam membantu dalam pelaksanaan kegiatan pondok.

6. Ketua Dewan Tanfidz bertanggung jawab kepada DPPAI.

7. Lembaga Pengabdian Masyarakat (LPM) dan Organisasi Santri Pondok Pesantren (OSPP) merupakan organisasi santri yang bersinergi dalam membantu menjalankan program pesantren.

Sebagai sebuah lembaga pendidikan yang berada langsung di bawah Yayasan Badan Wakaf, PP UII memiliki struktur kelembagaan yang jelas. Pemimpin harian berkewajiban memimpin jalannya proses pembelajaran di pesantren dan melaporkan secara berkala kepada rektor. Dalam proses pembelajarannya, pimpinan dalam hal ini Kiai atau pengasuh dan pengelola meminta para dosen yang memiliki kualifikasi sesuai dengan bidang keilmuan baik berasal dari lingkungan UII maupun dari luar UII. Dalam pemilihannya, PP UII sangat ketat, karena hal ini terkait profesionalisme dalam proses pengelolaannya, misalnya dari segi keilmuannya maka standarisasinya adalah minimal Strata 2 atau dari segi keahlian pada bidang-bidang tertentu. Prinsip profesionalisme ini merupakan prinsip dalam mewujudkan tata lembaga yang baik (good corporate governance). 
Prinsip profesionalisme ini pula terlihat dari proses pemilihan pimpinan harian atau pengasuh yang tinggal di PP UII. Terdapat kualifikasi khusus sebagai pimpinan di PP UII. diantaranya adalah capable, acceptable, memiliki kemampuan manajemen yang baik, saleh, berstrata pendidikan mininal magister, diutamakan yang berstatus dosen di lingkungan UII, kalaupun tidak, maka ia diketahui memiliki catatan yang baik di bidang keislaman dan keilmuan, dan diutamakan yang berasal dari alumni. ${ }^{31}$ Model kepemimpinan yang sangat demokratis sangat terlihat dalam pengelolaan Pesantren. Pimpinan Pesantren sangat memberikan ruang atau forum kepada santri untuk berbagi ide, gagasan baik menyangkut keilmuan maupun terkait program pesantren. Santri dapat melakukan kritik terhadap proses pembelajaran, kebijakan atau kegiatan lainnya. Meskipun demikian hal tersebut tidak menghilangkan penghormatan terhadap pimpinan pesantren. Kiai tetap memiliki otoritas dalam menentukan arah dan kebijakan Pesantren..$^{32}$ Pada tahap ini, model kepemimpinan leader oriented menjadi system oriented diaplikasikan di PP UII. Hal ini penting untuk menjaga konsistensi visi dan misi Pesantren meskipun terjadi pergantian pemimpin. Sistem yang diterapkan harus baku agar keberlangsungan proses dan tujuan didirikannya pesantren sesuai dengan harapan founding fathers. Tersebut ini merupakan ciri khas dari pengelolaan suatu lembaga yang baik. Orientasi pada sistem adalah hal penting dalam pengelolaan suatu lembaga. Siapapun yang memimpin, jika sistem yang diterapkan telah baku maka tujuan tidak akan berubah.

Prinsip pengelolaan tersebut sesuai dengan prinsip-prinsip dalam good corporate governance. Pimpinan harian tidak hanya bertanggungjawab terhadap proses keberlangsungan Pesantren terhadap pimpinan Universitas, tetapi juga bertanggungjawab kepada para santri. Setiap problem dan kegiatan pesantren selalu berada dalam pengawasan dan perhatian Pengasuh. Begitu halnya para santri yang diwakili oleh Organisasi Santri Pondok Pesantren (OSPP) yang turut melaksanakan program-program Pesantren

${ }^{31}$ Noor Hamid dan Muhammad Iqbal Juliansyahzen, "Prophetic Leadership in Pesantren Education: Study at Pondok Pesantren Universitas Islam Indonesia," 362-63.

${ }^{32}$ M Ainun Najib (Tenaga Pengabdian), wawancara. 
turut bertanggungjawab terhadap pimpinan pesantren. Pada setiap akhir kepengurusan, kegiatan-kegiatan yang telah dilaksanakan dipertanggungjawabkan secara langsung kepada pimpinan pensatren dan para santri.

Prinsip lainnya yang selalu diperhatikan adalah aspek transparansi. Aspek keterbukaan merupakan suatu hal yang penting dalam pengelolaan suatu lembaga. PP UII secara bulanan misalnya melaporkan proses kegiatan yang berlangsung kepada pimpinan dalam hal ini adalah rektor, khususnya dalam penggunaan laporan keuangan atau operasional. Dalam proses pembelajaran, para santri secara terbuka juga dapat mendapatkan informasi secara terbuka kepada pihak pengelola. Pada akhir semester, pengelola mengumumkan hasil evaluasi pembelajaran, bahkan jika terdapat salah satu santri yang mendapatkan peringatan karena nilai yang tidak mencapai standar, santri lainnya pun dapat mengetahuinya. Hal ini ditujukan agar para santrinya dapat memaksimalkan kemampuannya sebagai seorang santri sekaligus mahasiswa dalam mencapai hasil yang sebaik-baiknya.

Sistem pembelajaran yang didesain untuk melahirkan kedisiplinan dan bagian dari profesionalitas, PP UII mensyaratkan kepada para santri untuk selalu hadir pada setiap perkuliahan di Pesantren, paling tidak 75\%. Sedangkan bagi dosen dipersyarakatkan untuk masuk minimal 12 kali. Tentunya ini merupakan ikhtiar memperkuat sistem dan menanamkan kedisiplinan bagi para santri. Jika santri tidak mencapai batas minimal kehadiran maka santri tersebut tidak dapat mengikuti Ujian Akhir Semester (UAS) di Pesantren. Akibatnya, santri bersangkutan mendapatkan Surat Peringatan (SP). Jika terjadi untuk yang kedua, maka santri bersangkutan akan diberhentikan sebagai penerima beasiswa unggulan dari PP UII, meskipun status sebagai mahasiswa UII tetap. ${ }^{33}$

Dalam konteks akuntabilitas, yang memungkinkan lembaga untuk menerima evaluasi yang lebih baik dari luar juga diimplementasikan di PP UII. pada akhir tahun ajaran atau paruh semester, Pengasuh mengundang para dosen dan pengelola untuk mendengar masukan dan arahan serta evaluasi proses pembelajaran.

${ }^{33}$ Ustadz Iqbal Zen, M.H, wawancara. 
Pengasuh secara progresif mencoba melaksanakan masukan dari para dosen dalam pengembangan akademik dan kemajuan pesantren. Dalam hal pengambilan keputusan, pihak pimpinan pesantren melakukan kajian dan menerima masukan dari berbagai sumber. Di antara contoh bahwa pengasuh mengakomodasi masukan, misalnya dalam konteks pembelajaran yang juga diorientasikan pada pengembangan bahasa, dosen menilai bahwa aspek kebahasaan dalam kurikulum masih sangat kurang. Jika kemudian dimasukan dalam SKS akan merubah kurikulum maka hal tersebut tidak memungkinkan, maka solusinya ialah dimasukan dalam Satuan Kredit Partisipasi (SKP). ${ }^{34}$

PP UII merupakan lembaga pendidikan pensatren dikelola secara profesional. Profesionalisme ini dapat dilihat dari menejemen kepengurusan dan kelembagaan yang sangat sistemik. Hal ini juga terlihat misalnya dari proses seleksi mahasiswa. Tidak semua mahasiswa dapat menjadi penghuni PP UII. terdapat proses seleksi baik dari tahap seleksi berkas dengan berbagai persyaratan. Selain itu, tidak hanya proses seleksi mahasiswanya saja, tetapi pemilihan pengasuh yang bertugas sebagai pemimpin harian di pesantren tidak mudah. Berbagai persyaratan ditentukan seperti memiliki standarisasi keilmuan dengan dibuktikan dengan ijazah minimal strata 2, atau yang memiliki keilmuan dan kompetensi serta direkomendasikan, memiliki kesalihan, diutamakan berasal dari dosen yang berada di lingkungan UII. Begitu halnya dalam pemilihan dosen yang mengampu mata kuliah yang diajarkan di pesantren. Dalam hal administrasi dan keuangan, PP UII memiliki staf khusus yang diamanahi secara langsung oleh Rektor melalui Surat Perintah Kerja (SPK) sehingga hal-hal yang bersangkutan dengan surat menyurat dan keuangan dilaksanakan dengan baik.

Prinsip GCG lainnya ialah tanggung jawab. Dalam kepengurusan di PP UII, secara formal masing-masing posisi melakukan pertanggungjawaban terhadap wewenang yang diberikan. Sebagai pemimpin harian, pengasuh melakukan pertanggungjawaban kepada rektor dan juga kepada para santri. Masing-masing komponen

${ }^{34}$ Usulan tersebut secara langsung disampaikan oleh dosen Bahasa Arab yaitu Bakri Ahmad (Banglades) pada rapat dewan dosen. Hasil wawancara dengan Ustadz Iqbal Zen (Dosen PP UII), 21 Agustus 2018. 
memiliki kewajibannya masing-masing. Pengasuh berkewajiban membimbing dan mengarahkan arah tujuan pesantren. Santri dapat memberikan kritik dan opini terhadap kepemimpinan pengasuh tanpa menghilangkan penghormatan kepada pemimpin. Begitu hal dengan santri yang memiliki kewajiban-kewajiban seperti kewajiban mengikuti perkuliahan, tinggal di Pesantren, dan lain sebagainya.

\section{F. Simpulan}

Good Corporate Governance merupakan diskursus dan tawaran strategis yang menarik untuk dikaji kembali secara konseptual. Meskipun demikian, sebagian besar menyetujui bahwa konsep ini merupakan panduan dalam upaya penyelenggaran suatu lembaga. Secara prinsip-prinsip dalam GCG, sesuai dengan prinsip penyelenggaraan suatu lembaga dalam Islam. Meskipun Islam tidak secara eksplisit menyebutkan model kepengurusan suatu lembaga. Diantara prinsip tersebut adalah transparansi, akuntabilitas, profesionalitas, dan tanggung jawab. Islam hanya memberikan seperangkat nilai-nilai etis dalam penyelenggaraan suatu lembaga.

Dalam konteks penyelenggaraan pendidikan di PP UII, prinsip-prinsip tersebut telah dilaksanakan dengan baik meskipun perlu terus diperbaiki. Dalam prinsip akuntabilitas misalnya, PP UII menerima evaluasi yang lebih baik dari luar dalam perbaikan sistem dan proses pembelajarannya. Selain itu, PP UII juga dikelola dengan menggunakan sistem profesionalitas misalnya dalam hal seleksi penerima beasiswa PP UII, proses kepemimpinan dan pemilihan dosen sesuai dengan bidang keilmuan dan kompetensi. Begitu juga dengan prinsip lainnya seperti tanggungjawab dan transparansi juga diaplikasikan pada sistem kelembagaan di PP UII.

PP UII secara kelembagaan berada di bawah yayasan UII sehingga hal ini membedakan dengan Pondok Pesantren pada umumnya. Model pembelajaran yang menggabungkan dengan model pembelajaran pesantren tradisional dan modern dengan model Perguruan Tinggi. Penggunaan sistem pembelajaran model Sistem Kredit Semester (SKS) merupakan hal yang baru bagi suatu lembaga pendidikan pesantren selain pengkajian terhadap kitab turats dan pengembangan bahasa asing[.] 


\section{REFERENSI}

Adebayo, Mudashiru., Ibrahim, A.O. Bakare., Yusuf, Babatunde., \& Omah, Ishmael. "Good Corporate Governance and Organisational Performance: An Empirical Analysis" Vol. 4, No. 7(1) (2014).

Agus Salim. Teori dan Paradigma Peenelitian Sosial. Yogyakarta: Tiara Wacana, 2001.

Ahmad Darmaji, dkk. "Reaktualisasi Dharma Dakwah Islamiyah Kampus UII Demangan" Vol. 10, No. 1 (Juni 2014).

Atho' Lukman Hakim. "Pesantren dan Perubahan SosiaL" Vol. 1, No. 1 (Desember 2013).

“BPKP RI." Diakses 20 Agustus 2018. http://bpkp.go.id/dan/ konten/299/Good-Corporate.bpkp.

Britha Mikkelsen. Metode Penelitian Partisipatoris dan Upaya-upaya Pemberdayaan; Sebuah Buku Pegangan bagi Para Praktisi Lapangan. Jakarta: Yayasan Obor Indonesia, 2003.

Djauhari Muhsin. Sejarah dan Dinamika Universitas Islam Indonesia. Yogyakarta: Universitas Islam Indonesia, 2002.

Kasful Anwar US. "Kepemimpinan Kiai Pesantren: Studi terhadap Pondok Pesantren di Kota Jambi" Vol. 25, No. 2 (2010).

M Ainun Najib (Tenaga Pengabdian. wawancara, 16 Maret 2018.

Martin Van Bruinessen. Kitab Kuning, Pesantren dan Tarekat. Yogyakarta: Gading Publishing, 2015.

Mohammad Ali. Memahami Riset Perilaku dan Sosial. Bandung: Pustaka Cendikia Utama, 2011.

------Metodologi dan Aplikasi Riset Pendidikan. Bandung: Penerbit Pustaka Cendikia, n.d.

Nalim. “Good Corporate Governance dalam Islam." Diakses 21 Maret 2018. https://media.neliti.com/media/publications/37052ID-good-corporate-governance-dalam-perspektif-islam.pdf.

Noor Hamid, dan Muhammad Iqbal Juliansyahzen. "Prophetic Leadership in Pesantren Education: Study at Pondok Pesantren Universitas Islam Indonesia" Vol. 6, No. 2 (n.d.). 
“Peraturan Universitas Nomor 17/PU/Rek/VIII/2011 tentang Pondok Pesantren Universitas Islam Indonesia," n.d.

Prabaningrat, dan Widanaputra. "Pengaruh Good Corporate Governance dan Konservatisme Akuntansi pada Manajemen Laba" 10 (3), (2015).

“Statuta Universitas Islam Indonesia," n.d. Yogyakarta. Pasal 7, ayat 1. Juga, Pasal 12 ayat 1.

"Surat Rektor tentang Pedoman Penyelenggaraan Pondok Pesantren UII tahun 2002.," n.d.

Ustadz Iqbal Zen, M.H. wawancara, 15 Agustus 2018.

Ustadz Muhammad Anas, S.Pd.I. wawancara, Juli 2018.

Wajdi Ben Rejeb, dan Mohamed Frioui. "The Impact of Good Corporate Governance Practices on Stakeholders Satisfaction in Tunisian Listed Companies" 4 (2) (2012). 


\section{INDEKS ARTIKEL}

\section{AKADEMIKA JURNAL PEMIKIRAN ISLAM}

Volume 22 No.02 Juli - Desember 2017

\begin{tabular}{|c|c|c|c|}
\hline No & Judul & Penulis & Hal \\
\hline 1 & $\begin{array}{l}\text { PERAN PESANTREN } \\
\text { DALAM WACANA } \\
\text { DAN PEMBERDAYAAN } \\
\text { MASYARAKAT MADANI }\end{array}$ & $\begin{array}{c}\text { Wahyudin } \\
\text { Halim }\end{array}$ & $191-218$ \\
\hline 2 & $\begin{array}{l}\text { PEMIKIRAN ISLAM } \\
\text { TERHADAP GENDER DAN } \\
\text { PEMBERDAYAAN PEREMPUAN } \\
\text { (STUDI PEMIKIRAN DAN } \\
\text { MODEL PEMBERDAYAAN } \\
\text { NYAI DI PONDOK PESANTREN } \\
\text { NURUL JADID PAITON) }\end{array}$ & $\begin{array}{l}\text { Siti } \\
\text { Mahmudah } \\
\text { Noorhayati }\end{array}$ & $219-244$ \\
\hline 3 & $\begin{array}{l}\text { PENGEMBANGAN BANK } \\
\text { SAMPAH SYARIAH } \\
\text { IKHTIAR PEMBERDAYAAN } \\
\text { MEMAJUKAN EKONOMI } \\
\text { KREATIF (STUDI BANK } \\
\text { SAMPAH CANGKIR HIJAU) }\end{array}$ & $\begin{array}{l}\text { Bambang } \\
\text { Suhada dan } \\
\text { Dharma } \\
\text { Setyawan }\end{array}$ & $245-266$ \\
\hline 4 & $\begin{array}{l}\text { GERAKAN TABLIGHI DI } \\
\text { KALIMANTAN TIMUR: } \\
\text { DEMAZHABISASI ISLAM, } \\
\text { EKONOMI “KETUHANAN" } \\
\text { DAN NARASI KONFLIK }\end{array}$ & $\begin{array}{l}\text { Saipul } \\
\text { Hamdi }\end{array}$ & $267-296$ \\
\hline 5 & $\begin{array}{l}\text { KONSOLIDASI KAPITAL } \\
\text { SOSIAL PEMULUNG SAMPAH } \\
\text { TEMPAT PEMBUANGAN } \\
\text { AKHIR SAMPAH KARANGREJO } \\
\text { KOTA METRO }\end{array}$ & $\begin{array}{l}\text { Ahmad } \\
\text { Madkur, } \\
\text { Suhendi, dan } \\
\text { Muhammad } \\
\text { Nasrudin }\end{array}$ & 297-318 \\
\hline 6 & $\begin{array}{l}\text { ANALISIS PERAN } \\
\text { KEAGAMAAN TERHADAP } \\
\text { PROSES PENDIDIKAN KURSUS } \\
\text { BAHASA INGGRIS (STUDI } \\
\text { KASUS DI KAMPUNG INGGRIS } \\
\text { PARE KEDIRI JAWA TIMUR) }\end{array}$ & $\begin{array}{l}\text { Muhamad } \\
\text { Abdul Aziz }\end{array}$ & $319-344$ \\
\hline
\end{tabular}




\begin{tabular}{|c|c|c|c|}
\hline No & Judul & Penulis & Hal \\
\hline 7 & $\begin{array}{l}\text { MEKANISME QUR'ANI } \\
\text { PENGELOLAAN KEUANGAN } \\
\text { PUBLIK }\end{array}$ & $\begin{array}{l}\text { Rosidin } \\
\text { Rosidin }\end{array}$ & $345-360$ \\
\hline 8 & $\begin{array}{l}\text { PEMBERDAYAAN } \\
\text { PEREKONOMIAN } \\
\text { MASYARAKAT MELALUI } \\
\text { KOPERASI UNIT DESA } \\
\text { BERBASIS USAHA TERBIMBING }\end{array}$ & $\begin{array}{c}\text { Erlina } \\
\text { Rufaidah }\end{array}$ & $361-374$ \\
\hline 9 & $\begin{array}{l}\text { MEMBANGUN KEKUATAN } \\
\text { NILAI PERJANJIAN } \\
\text { SYARIAH DALAM UPAYA } \\
\text { MENINGKATKAN KINERJA } \\
\text { KARYAWAN BANK SYARIAH } \\
\text { DI INDONESIA }\end{array}$ & $\begin{array}{l}\text { Ayus Ahmad } \\
\text { Yusuf, } \\
\text { Layaman, } \\
\text { dan Wartoyo }\end{array}$ & $375-402$ \\
\hline 10 & $\begin{array}{l}\text { AN ANALYSIS OF ZAKAH } \\
\text { FUNDS THROUGH } \\
\text { COMMUNITY BASED } \\
\text { DEVELOPMENT }\end{array}$ & $\begin{array}{l}\text { M. Ihsan } \\
\text { Dacholfany } \\
\text { dan Nedi } \\
\text { Hendri }\end{array}$ & $403-418$ \\
\hline
\end{tabular}

